\title{
As leituras antijesuíticas do romance histórico As Minas de Prata, de José de Alencar
}

Rafaela Mendes Mano Sanches ${ }^{1 *}$

\section{Resumo:}

Em meados do século XIX, as sucessivas leituras de $O$ Judeu Errante, obra francesa de temática antijesuítica, fomentam polêmicas e discussões no âmbito político e literário na imprensa do Rio de Janeiro. No trânsito entre esfera pública e literária, o enredo do folhetim francês é tonalizado pelo quadro local, sendo recriado e readaptado em outros textos literários brasileiros, caso do romance histórico As minas de Prata, de José de Alencar. Neste trabalho, analisaremos a prosa de caráter histórico alencariana, a partir da reconstituição de algumas controvérsias em torno do romance francês, na tentativa de fornecer a produção de sentidos por parte do leitor, e de apreender as possíveis reapropriações dessa narrativa em As Minas de Prata.

Palavras-chave: folhetim francês; reapropriação; antijesuitismo.

\begin{abstract}
:
Towards the mid-19th century, successive readings of O Judeu Errante (The Wandering Jew), an anti-Jesuit French thematic work, foster discussions and controversies in both political and literary context in the press of Rio de Janeiro. In transit between the public and literary sphere, the plot of the French serial is toned by the local context, being rebuilt and refitted in other Brazilian literary texts, such as the historical novel As Minas de Prata (The Silver Mines), by José de Alencar. In this paper, we analyze Alencar's historical prose, from the reconstitution of some controversies surrounding the French novel, in an attempt to provide the production of meanings by the reader and to grasp the potential reappropriations of such a narrative to As Minas de Prata.
\end{abstract}

Key-words: French serial romance; reappropriation; anti-Jesuit.

\section{Introdução}

Separados por duas décadas, o folhetim francês $O$ Judeu Errante, de Eugène Sue, é publicado na rubrica Folhetim do Diário do Rio de Janeiro entre os anos de 18441845, e o romance As Minas de Prata, de José de Alencar, é lançado pela Bibliotheca Brasileira de Quintino Bocaiúva em 1862, com dezenove capítulos iniciais e com o título As Minas de Prata: continuação do Guarani. Somente em 1865, José de Alencar retoma sua obra e a publica em seis volumes, pela editora B. L. Garnier, fazendo

\footnotetext{
${ }^{1}$ Doutoranda no Instituto de Estudos da Linguagem, IEL, da Universidade Estadual de Campinas, UNICAMP, Campinas, São Paulo, Brasil. rafaelamsanches@gmail.com
} 
algumas modificações na primeira versão: retira notas, altera o próprio título e acrescenta outros capítulos. Apesar de escritos em momentos e contextos diferentes, as obras aproximam-se na concepção de procedimentos estéticos e, sobretudo, temáticos de suas narrativas, ao reaproveitarem o tema da literatura antijesuítica. Essa temática gera pontos de contato entre o romance francês e o brasileiro, e possibilita relações aproximativas e/ou relações distanciadas, a partir dos diálogos que as representações estéticas de caráter jesuítico criam e estabelecem com uma rede de sociabilidade, constituída, em parte, pelas discussões, debates e controvérsias que movimentam esse assunto na imprensa fluminense das décadas de 1840 e 1850. Os possíveis diálogos, empréstimos e reinterpretações que podem ter acometido a reescrita da Companhia de Jesus em As Minas de Prata, em consonância com o debate crítico e literário em torno de $O$ Judeu Errante, dão sentidos aos expedientes e recursos literários empregados por Eugène Sue para situar seu folhetim na série de leituras antijesuíticas na França, convalidadas, posteriormente, por José de Alencar.

Segundo Leroy (1999), o momento de produção da referida prosa francesa, na França da Monarquia de Julho, compreende um contexto de confronto e combate aos inacianos, uma encruzilhada de conflitos, embasada nas disputas entre Universidade e Colégio da Companhia. As leituras desse cenário francês entrariam em conformidade com o alcance da natureza anticatólica do folhetim de Sue na imprensa fluminense ${ }^{2}$ e, nesse ponto, o repertório de referências da trama de $O$ Judeu Errante contribui, em certa medida, nas adaptações das críticas à Corporação Religiosa na obra de Alencar. A prosa alencarina recontextualiza e requalifica as propagandas negativas dos loiolanos, que, formalizadas nas apropriações e interdições contrárias à Instituição no período da reforma protestante, constroem e reconstroem o mito jesuítico no decorrer de séculos. As condições do chamado "mito negro" dos inacianos no Brasil podem ser investigadas nos movimentos de contestação às práticas eclesiásticas da Companhia, em tensão com os modelos de representações sobre as quais a literatura é confeccionada.

Neste texto, reconstituiremos brevemente o lugar dos jesuítas na imprensa do Rio de Janeiro da década 40, e o momento de recepção de O Judeu Errante. Em

\footnotetext{
${ }^{2}$ Nosso estudo da imprensa apreende os periódicos de maior circulação e periodicidade no Rio de Janeiro, como o Diário do Rio de Janeiro e o Correio Mercantil, além de levantar outros que apresentam debates significativos sobre os jesuítas. Dessa maneira, tentamos buscar uma possível pluralidade na representação dos jesuítas nesse espaço.
} 
seguida, estudaremos a referida Ordem no folhetim francês e suas readaptações e pontos de contato em As Minas de Prata.

\section{O teor antijesuítico de As Minas de Prata}

O fenômeno do antijesuitismo acompanhou a reafirmação e a expansão da religião cristã em diferentes espaços nacionais, desenvolvendo-se em todos os cenários em que os loiolanos tiveram alguma ação. De acordo com Leroy (1999), o mito jesuíta na França do século XIX ganha eficácia máxima pelas sátiras de Berenguer, e pelo romance $O$ Judeu Errante. Para o autor, o processo do mito se constrói pela repetição e reiteração de argumentos antijesuítas, escritos e reescritos desde a fundação da Companhia, constituindo uma literatura de oposição à Ordem, cujas imagens são reelaboradas pelos detratores da Instituição. O Judeu Errante faz parte desse processo:

\footnotetext{
Através desta narração impregnada de fantástico, o leitor encontrava os principais elementos do mito jesuíta na França de 1832: a atividade prejudicial de uma sociedade secreta com numerosos e poderosas ramificações, a busca obstinada da riqueza e do poder através os meios mais criminosos, a astúcia, a violência e a perseguição de uma família protestante de geração em geração, a obtenção de heranças, a influência exercida sobre as mulheres através da confissão. Ao antijesuitismo tradicional, E. Sue misturava novos ingredientes, especialmente um interesse novo pela questão social, que será resolvida pela associação. [...] É o contraste entre dois tipos de associação que se pretende simbolizar: a associação perversa que visa o poder per fas aut nefas e a associação virada para a liberdade, para o progresso dos homens. (LEROY, 1999, p. 96).
}

Do outro lado do atlântico, a produção de sentidos da obra francesa nos periódicos do Rio de Janeiro da década de 1840 e 1850 é proporcional às formas plurais de representar a Instituição Eclesiástica nas práticas da imprensa, que transformam os procedimentos de criticidade de Sue no referencial crítico e representativo sobre a Ordem, em uma interlocução com o contexto brasileiro. Nesse período, os "homens de letras" discutem questões como a eficácia dos jesuítas na catequese, as práticas politizadas da Ordem, e a concorrência do poder dos inacianos com o Estado. Nos apontamentos do Instituto Histórico e Geográfico Brasileiro (IHGB), os inacianos inscrevem-se no processo civilizatório do Brasil Colonial, sobretudo, pelo exercício da catequese, que, em parte, articula o discurso laudatório em torno dessas figuras 
religiosas. No reverso disso, o discurso histórico do Instituto reescreve as disputas dos eclesiásticos com outras esferas de poder, fato que levanta objeções a respeito do possível retorno da Instituição no período contemporâneo a Alencar.

No Brasil, o processo da reinvenção dos jesuítas no Brasil fomenta-se por reinterpretações e sistematizações marcadas, por um lado, pela circulação e consolidação da literatura antijesuítica entre as décadas de 1830-1860 na imprensa fluminense e no IHGB, e, por outro, pela mitificação dos primeiros missionários no Brasil representada pelos mesmos espaços. Interagindo com essa rede de sociabilidade, As Minas de Prata representa na sua estrutura romanesca o movimento de criação da Companhia de Jesus, movimento que resgata o discurso controverso, exaltado e opositor que, desde o surgimento da Corporação, demarcou dissidências no próprio seio da esfera eclesiástica.

Dessa maneira, entender os sentidos dos jesuítas na obra alencariana se faz indissociável do espaço da literatura na esfera política do país, ou antes, da compreensão das funcionalidades, do impacto e das significações da Ordem nas malhas jornalísticas, caracterizadas por uma rede de debate polifônico. As propagandas negativas dos inacianos formalizam em certa medida uma engrenagem de combate ideológico, pois, utilizadas, alegadamente, para a "liberdade sociopolítica", bem como para atacar a religião cristã, elas confrontam e denunciam os efeitos causados pelos loiolanos nos planos político, religioso, e econômico.

As Minas de Prata compõe um movimento de contestação à Ordem, e, na contrabalança, um movimento de apreciação dos loiolanos missionários. A trama recorre a situações nas quais a Instituição entra em conflito com o poder governamental e com doutrinas dissidentes entre si. No cerne deste conflito, a oposição do personagem jesuíta Inácio Louriçal ao relaxamento moral e à adaptação antidogmática exercidos pelo seu companheiro Molina suscita inquietação e suspeitas quanto aos aspectos da politização da Ordem.

A narrativa explora os conflitos históricos da colônia brasileira no início dos seiscentos, momento em que o Colégio da Companhia dominava o ensino e disputava poderes com o governo. A obra se debruça criticamente na postura do padre Visitador Molina, e no seu trajeto na Companhia, que envolve uma série de polêmicas e intrigas, seja na sua intromissão no Colégio, momento em que anuncia sua nomeação como padre Supervisor, substituindo o inaciano Fernão Cardim; nos seus ideais que 
sobrelevam o acúmulo de funções; e nas suas atitudes manipuladora perante outros jesuítas.

A prosa de natureza histórica consegue ficcionalizar as querelas jesuíticas já na primeira cena da Ordem Religiosa:

\begin{abstract}
Ao longo da sala estava uma mesa comprida, carregada de instrumentos astronômicos e matemáticos, de tinteiros, livros e papéis; aí, sentados, diversos religiosos aproveitavam a manhã para realizarem os trabalhos de paciência e estudo, que são o mais precioso legado deixado por essa Ordem à civilização moderna.

Muitos copiavam manuscritos de história; outros traduziam em guarani as orações cristãs para uso dos indígenas; estes se entregavam a estudos de botânica e classificavam uma planta brasileira ainda desconhecida; aqueles tiravam a limpo suas observações astronômicas; alguns escreviam crônicas das religiões, ou cartas sobre o estado das reduções.

Quem visse esses homens, assim ocupados em marcarem com o selo de sua inteligência todos os conhecimentos, em ligar seu nome, não já à religião, mas à história, à geografia, à política, à filosofia e até as artes, não se admiraria que, unidos pelos mesmo pensamento e dirigidos por uma só vontade, houvessem criado a Ordem poderosa que, espalhando-se pelo mundo, dominou os tronos, curvou os reis, e lutou com os governos das mais fortes nações. (ALENCAR, 1958, p. 473 , grifo nosso).
\end{abstract}

Essa descrição de suas funções, antes mesmo de apresentá-los, permite antecipar as indagações e representações das tarefas eclesiásticas, a partir de caracterizações que inserem uma dinâmica concorrencial e a prática capitalista nas doutrinas da Instituição. Estes tópicos aqueciam os debates na imprensa. Por um lado, os jesuítas fizeram a história do Brasil e contribuíram com seus estudos e pesquisas no âmbito da ciência, da história, da etnografia, da geografia; por outro, a ambição desmedida, que é tracejada nessa primeira apresentação, é inversamente proporcional aos princípios tradicionais do catolicismo.

Com essa descrição e julgamento de valor, a narrativa demarca seus aspectos e traços de historicidade, bem como o senso histórico subjacente à escolha de ângulo focalizado para narrar o chamado "mito negro jesuítico" e suas funcionalidades no Brasil, em um estreito diálogo com suas redes de interlocução. Dentre elas, daremos destaque à recepção crítica de $O$ Judeu Errante, posto que dialoga com as leituras precursoras da formação de uma tradição anticatólica.

Os jesuítas na imprensa fluminense da década de 1840 e a recepção de $O$ Judeu Errante 
Levando em conta que a leitura é sempre uma prática encarnada em gestos, espaços, hábitos (CHARTIER, 1991), reconstruiremos as leituras sobre a Companhia no espaço da imprensa fluminense, visto que O Judeu Errante entra em constante diálogo com a realidade social representada nos periódicos. Dessa maneira, os debates e controvérsias em torno do romance e em torno dos jesuítas nos noticiários, sobretudo, na parte superior dos jornais, entram em contato com o rodapé na parte inferior, parte destinada à publicação de romances. No nosso estudo, notamos a circulação da prosa ficcional de temática anticatólica na rubrica Folhetim, de modo que a organização espacial dos periódicos e a natureza de informações e representações que são veiculadas na sua estrutura, fornecem as possíveis práticas de leitura no espaço em que a obra francesa é publicada. Para o leitor daquela época, a esfera cultural se coaduna com o noticiário político e econômico que coloca em cena a literatura antijesuítica.

Em vários jornais fluminenses da década de 1840, observamos, em geral, notícias sobre a expulsão dos jesuítas em vários países e suas relações com partidos políticos retrógrados e com ideais antilibertários, e, principalmente, notamos a configuração de noticiários ligados à polêmica sobre a influência dos loiolanos na esfera do ensino. Aliás, em um fluxo contínuo, a Ordem Inaciana é redimensionada em contextos de perseguição e de despotismo, de forma que os recortes nos permitem reconstituir um eixo referencial sobre essa Instituição. Se em grande parte das publicações, os loiolanos aparecem como religiosos que desprestigiam seus partidos políticos e que são integrantes de uma Instituição decadente; em outras, aparecem como eclesiásticos que possuem doutrinas e ações meritórias. Porém, a publicação de notícias recentes e mais contemporâneas aos oitocentos desafia os textos elogiosos sobre a Corporação, principalmente, por estes terem como baliza e estratégia o retorno ao passado da Ordem. Uma vez que os jesuítas representados nos jornais estão conectados a imagens da Santa Aliança e à ausência de liberdade, essa realidade narrada concorre com o resgate do lado progressista e atemporal da Companhia. E aqui podemos destacar textos políticos reinterpretando as Monita Secreta $^{3}$, e textos com possíveis

\footnotetext{
${ }^{3}$ O libelo as Monita Secreta (Instruções Secretas sobre a Ordem Religiosa), escrita por um jesuíta polaico, expulso da Companhia de Jesus, ganha circulação nos momentos de produção dos romances analisados. Escrito no século XVII, a propaganda antijesuítica levantaria suspeitas quanto a sua autenticidade, e reencontraria releituras favoráveis a sua circulação, servindo a um movimento internacional contra o catolicismo. Segundo Leroy (1999), as Monita secreta é um poderoso testemunho da mentalidade conspiracionista jesuítica. Para este crítico, o autor das Instruções revelaria, ao cabo de 17 capítulos, as estratégias manipuladas pela Ordem para diversas finalidades, como adquirir bens, captar a confiança de poderoso, aumentar a riqueza da sociedade, conquistar viúvas ricas, afastar outras ordens.
} 
desdobramentos do quadro filosofia x religião, rearranjados em leituras que defendem uma sociedade mais libertária. Os discursos detratores mantém dinamicidade com a contemporaneidade, enquanto o discurso favorável se esquiva das acusações que pesam na atualidade dos oitocentos. Os recorrentes ataques e objeções do movimento antijesuítico acompanham os confrontos dos inacianos com as transformações sociopolíticas. O estudo de Franco (2007, p.276) sobre a atuação dos jesuítas, após sua restauração em 1815, dialoga com os debates em circulação nesse período:

A Companhia de Jesus, associando-se e aceitando ser um instrumento de relevo no ideário restaurador do terreno de influência, perdido pela Igreja, na sociedade em crescente processo de secularização, tendo por base o modelo antigo de Cristandade, teve dificuldades em compreender, dialogar, e aceitar as novas derivas da história humana.

O desajuste dos eclesiásticos com as modificações sócio-culturais reitera o fenômeno do antijesuitismo e, no caso do Brasil de 1840-1860, a dissonância da prática dos loiolanos com a política de conservação do Império provoca adoções de medidas restritivas à Instituição Inaciana, as quais são incorporadas na política de conciliação, cujo posicionamento preserva o Estado da concorrência religiosa, ao mesmo tempo em que insere os inacianos no passado nacional ${ }^{4}$. O discurso político oitocentista fomenta um ritmo de combate aos métodos jesuíticos, e ganha tônus em meados da década de 40. Nesse período, a questão dos jesuítas aquece as penas dos folhetinista e redatores brasileiros, e proporciona uma crescente querela, sobretudo, marcada por respostas às acusações levantadas contra os loiolanos, principalmente, após a publicação de $O$ Judeu Errante. Exemplo disso, é a revista Guanabara, que, ao circular uma análise do épico $O$ Uruguai, de Basílio da Gama, aproveita o momento para estudar a presença dos jesuítas no poema e para defendê-los diante da crítica contemporânea. Nesse caso, o autor parte da disseminação de uma literatura antijesuítica "nestes últimos tempos", podendo se abster de conceituá-la:

[...] O quinto e último canto do poema nos descreve, pintadas nas abóbodas do tempo principal das missões, todas as maldades da Companhia de Jesus. Deixo de falar acerca delas, porque assáz se tem falado e escrito a tal respeito nestes últimos tempos, e por acaso se

\footnotetext{
${ }^{4}$ Os estudos de Domingos (2009) relativos à polêmica sobre os jesuítas na Revista do IHGB desenvolvem os problemas da Ordem com a política imperial.
} 
encontrará uma só pessoa que não haja lido pelo menos o Judeu Errante de Eugenio Sue.[...]

É sabido que os incrédulos vergonhosos, que não se atrevem a atacar diretamente a religião católica, se desafogam insultando aos jesuítas, e isto por tão diverso modo, que os averbam num país de liberais e demagogos, e num outro de servis e absolutistas. No meu entender os jesuítas é uma corporação de homens honestos e ilustrados, posto que algum tanto ambiciosos, sendo esta a causa da cruenta guerra que lhe move o vulgo. Basílio da Gama, ingrato para com eles, pois lhes devia sua educação, posição e tudo o que era, seguiu nisto as ideias vulgares, apesar das suas luzes. (Guanabara, [184?], p. 316-317).

No trecho, fica evidenciado o peso da propaganda contra os eclesiásticos na década de 40, inclusive, pela circulação do romance-folhetim de Sue. Ainda que o autor assuma o lado ambicioso dos inacianos, não lhes tira a imagem de homens que contribuem para a igreja católica. Ou seja, tomar partido dos loiolanos implica em limpar a imagem da Igreja Católica no Brasil. Sendo assim, compreender as significações atribuídas ao Judeu Errante é relevante na medida em que as formas de organizar e apreender as perspectivas sobre a Companhia tomam novos rumos.

Segundo Vitorino (2002), O Judeu Errante teve uma enorme popularidade para os padrões da época. Para este crítico, o sucesso da obra estaria explicado pelo fato de ela ser antijesuítica, o que mobiliza discussões entre os representantes clericais e seus opositores, alcançando, inclusive, o palco político.

Entre as décadas de 1840 e 1860, podemos notar que as maneiras de ler a referida prosa são partilhadas das formas de pensar do público letrado sobre a religião católica no Brasil. Os discursos jornalísticos demarcam posições controversas, manifestadas na tensão entre a depreciação do texto de Eugène Sue pelos letrados de inclinação religiosa; e a apreciação da narrativa por aqueles que combatem o catolicismo, representados pelo discurso que encontra estratégias para legitimar a veracidade do enredo folhetinesco e adequá-lo a determinadas conjeturas.

Do lado dos detratores, Padre Miguel do Sacramento Lopes Gama se destaca com a obra Observações críticas sobre o romance do senhor Eugène Sue: O Judeu Errante (1850), e com a escrita do opúsculo O Mal considerável da maior parte dos romances (1852), que, após sua morte, é dividido em 13 artigos e lançado no Correio Mercantil (1859. As reflexões do padre confluem para uma análise moralista do folhetim de Sue, tendo em vista sua formação sacerdotal que contribui para seus ataques contra objeções aos dogmas católicos. Por um lado, Gama concorda que Sue elogia o Evangelho, porém, de outro, centraliza em suas críticas acusações anticlericais ao 
folhetim, visto que, segundo o padre, era necessário mostrar a imoralidade de certos romances e novelas.

Com este objetivo, no escrito Mal Considerável da maior parte dos Romances, Gama aponta os inconvenientes morais dos romances que eram considerados populares naquele período:

Eugène Sue no seu abominável Judeu Errante parece um fiel discípulo do filósofo de Genebra. Protestante apaixonado, o seu ódio ao catolicismo aparece em quase todos os seus romances; e as personagens do seu drama não funcionam senão para proferir máximas de incredulidade. A sua Adriana, princesa de Cardoville, é um compêndio de graças; mas é uma jovem que não respira senão para prazeres e vaidades. Namora-se perdidamente de um príncipe chamado Djalma, e quando tratam de unir-se pelos laços conjugais dai tira o romancista motivo para por intermédio dessa jovem filosofante fazer uma dissertação contra o sacramento do matrimônio, e ao mesmo tempo reprovar alta e poderosamente a indissolubilidade de seus laços! (Correio Mercantil, 15/02/1859, p. 2).

Onde se viu em escritos populares, como o Judeu Errante, procurar por meio da magia do estilo deprimir e infamar os laços sagrados que unem os consortes, bem como a família e a sociedade inteira? Que outro fruto se pode colher de menosprezar e aviltar o sacramento do matrimônio senão o de tornar desprezível o estado conjugal? (Correio Mercantil, 18/02/1859, p.2).

No trecho citado, Lopes Gama destaca o movimento protestante que aparece nos romances de Eugène Sue, cujo objetivo seria atacar os princípios e a moralidade da Igreja Católica e da sociedade. O crítico ainda censura a composição do personagem jesuíta Gabriel, de $O$ Judeu Errante, que desconfia das doutrinas e das concepções pregadas pela Corporação Inaciana. Nesse caso, Lopes tenta esclarecer as estratégias que o literato francês utiliza para desconstruir os dogmas da Igreja Católica. Segundo o crítico brasileiro, ele faria referência a Deus e a Jesus Cristo apenas para apontar o lado corrupto do catolicismo, em defesa do movimento protestante. Dessa forma, o jesuíta Gabriel posicionar-se-ia contra as doutrinas praticadas por seus superiores, o que, segundo Lopes, potencializaria a reprovação do catolicismo, por parte do romance. Para o padre, os posicionamentos de Gabriel representariam a religião protestante e a corrente filosófica do século XVIII. ${ }^{5}$

\footnotetext{
${ }^{5}$ Em "O Mal Considerável da maior parte dos Romances, o padre Lopes Gama mostra como a "verdade" da filosofia e dos homens tenta sobrepor-se à de Deus, e como os "filosofantes" tentam provar que o progresso da humanidade é devido à filosofia do século XVIII. Discordante disso, dá vários exemplos de 
O periódico $A$ voz da Religião ${ }^{6}$ também publica um texto crítico ao folhetim $O$ Judeu errante, assentado na obra Des jésuites et de quelques engouments litteraires à propos du Juif Errant, de Victor July. Transcrevendo as argumentações de Joly, o jornal critica o caráter antijesuítico do referido romance e sua blasfema à boa moral, pois, de acordo com o autor francês, o romance seria uma forma rápida de disseminar calúnias, e, no caso de $O$ Judeu Errante, seu objetivo seria enterrar o catolicismo.

O texto do estudioso francês analisa a obra de Sue da perspectiva religiosa catolicismo X protestantismo, comentando a inclinação anticatólica do folhetim, pois, para o crítico, o livro é uma sátira à igreja católica. De acordo com o escritor, isso seria essencial para encontrar admiradores em países como a Alemanha luterana, Inglaterra protestante, e em todos os demais onde o catolicismo é perseguido e escravizado. Em contraponto, Joly defende os jesuítas apresentando testemunhos de suas manobras desde a época do surgimento da Companhia. A Voz da Religião confronta sua defesa com o "mal da religião" - os filósofos e "libertadores": "Todos estes libertadores dos povos, que vem emancipar a humanidade, uma vez que se firmam no poder, exercem o mais insolente e iníquo despotismo.", sintetizando o duelo entre religião e "liberdade", tópica discutida nesse período: "Não se trata portanto dos Jesuítas, nem dos perigos do jesuitismo, trata-se de um duelo de morte entre Catolicismo e a liberdade.... Trata-se de uma luta entre o racionalismo liberal e as grandes tradições cristãs." (A Voz da Religião, 18/02/1849, n. 164, p.72, grifo nosso.). Sendo assim, a oposição entre catolicismo e filosofia é rearticulada e ressignificada em distintas leituras, acompanhando a temática de $O$ Judeu Errante.

Observamos o aproveitamento dessa oposição em As Minas de Prata, porém, em outras condições. Nas referências à Guerra Holandesa, a narrativa confecciona personagens protestantes representados pelos holandeses presos no forte, e, sobretudo, pelos holandeses que tomariam a cidade de Salvador, e, em contraste, constitui personagens cristãos, que protegem o litoral baiano. Porém, os conflitos entre os métodos e doutrinas das duas religiões entre si não são colocados em pauta. $O$

que as conquistas sociais são feitos católicos e que, dentre elas, os ideias de fraternidade, igualdade e liberdade são confluentes das doutrinas do próprio catolicismo.

${ }^{6}$ A Voz da Religião é um periódico publicado em Pernambuco, porém, justificamos sua análise perante nosso recorte da imprensa flumimense, em função da recepção que esse jornal faz de uma determinada crítica francesa sobre $O$ Judeu Errante, o que poderia abrir pistas sobre a circulação da literatura antijesuítica no Brasil. 
personagem Molina, apesar de incorporar o jesuíta maquiavélico, passa por um processo de redenção. É criticado o lado político da Companhia, o que, de fato, pode ser uma releitura do folhetim francês, entretanto, não é descartado o seu lado espiritual. Nossa hipótese é de que José de Alencar contraria o lado político da Ordem Inaciana, mas não seu lado missionário.

As leituras contrárias ao romance $O$ Judeu Errante produzem os paradigmas de discussão estética e consolidam referências para desprestigiar outras publicações que rivalizam com os princípios católicos. Nesse sentido, um leitor, sob o pseudônimo de “O Catholico Romano" (Correio Mercantil, 05/12/1850, p. 3), critica o lançamento do folhetim do Jornal do Commercio "A Sobrinha do Conego", de J. J.Teixeria, por conta da visão negativa dos jesuítas representada por tal romance, que, para ele, junto com outras obras como O Judeu Errante, confundiria o leitor. Segundo esta crítica, muitos leitores não saberiam discernir ficção de realidade e acreditariam que a pintura dos loiolanos nestas mencionadas obras seriam verídicas.

O impacto do folhetim francês na avaliação do papel negativo da Companhia mobiliza interesses e objetivos divergentes. Se a obra de Sue é apontada como mentirosa, inverossímil, e caluniadora por seus detratores, ou mesmo, como uma narrativa que confundiria o leitor, a tentativa de dar veracidade e credibilidade a seus escritos por parte dos defensores chega, inclusive, à publicação de uma "narrativa verídica" que seria semelhante a de Sue. Sob o título de "Um Novo Rennepont" (Diário do Rio de Janeiro, 30/06/1846, p. 2), é extraído da "Restauração da Carta", um texto que atesta a veracidade de O Judeu Errante mostrando um caso similar em Roma, onde os jesuítas tomam a herança de um mancebo de Bolonha, que, apresentando um estado frágil de saúde, é influenciado pelos inacianos e deixa sua herança à Companhia de Jesus. A circulação dessa notícia não só legitima e consagra a formulação negativa do mito jesuítico, mas também concede uma certidão de verdade à ficcionalização de Sue, desfazendo a pecha de "obra inverossímil”.

As percepções estéticas do romance articulam os traços e ingredientes fundamentais que o leitor encontrará reestruturados nas ações do jesuíta Molina, de As Minas de Prata: "Há entretanto nesse romance [O Judeu Errante] uma magnífica criação; a de Rodin, aquele padre jesuíta que de sua alcova nua e glacial governa o mundo inteiro [...]"'(Correio Mercantil,16/09/1857, p. 1). Esse trecho é extraído de uma correspondência de Paris, citada no jornal, e deixa bem claro a representação do poder dos inacianos no romance-folhetim. O corrupto e ganancioso Molina pode ser visto 
como uma readaptação dos procedimentos de Rodin. O leitor vai encontrar Molina sob as vestes de Rodin, o que abre o horizonte de expectativas com relação ao romance.

Absorvendo as principais polêmicas do momento, a prosa de caráter histórico alencariano retraça o movimento de contestação à Instituição Religiosa, ao explorar as ações pérfidas dos inacianos. Antecipamos que os métodos jesuíticos explorados por $O$ Judeu Errante, e comentados criticamente por Padre Lopes e pelos letrados que defendem a religião, são retomados em As Minas de Prata. Essa narrativa literariza os aspectos negativos dos inacianos proporcionalmente à expansão da Ordem no Brasil Colonial e sua imersão por outras áreas e saberes. As ações de Molina impregnam-se de acusações, suspeitas e insinuações por parte da voz da narrativa e por parte das vozes de personagens, fatores que nos levam a pensar numa apreciação do romance sobre o próprio discurso controverso da Companhia, cujo processo difamatório acompanhou seu surgimento. Ou seja, tais vozes simbolizariam as críticas enraizadas nos primeiros anos da Corporação, e rearticuladas na rede de interlocução de Alencar. Posto isso, passaremos a analisar o folhetim francês e seus diálogos com a obra de Alencar, bem como as reinterpretações dadas pelo romance alencariano.

\section{Os maquiavélicos jesuítas de O Judeu Errante e de As Minas de Prata}

O lado maquiavélico dos loiolanos nas duas narrativas pode ser entendido e interpretado a partir de projetos e programas poucos éticos da Companhia para levantar fundos monetários, que são representados no Brasil seiscentista ou no Imperial, e na França após a Revolução de 30. Por esse caminho, a imagem do poder oculto da Companhia, por um lado, e a de fantoche, empregada para simbolizar as pessoas envolvidas na Ordem, por outro, ambas exploradas em O Judeu Errante, são ressignificadas em As minas de Prata, posto que, da mesma forma que os jesuítas do romance francês manipulam pessoas que desconhecem o verdadeiro intuito dos inacianos, Molina também abusa da boa fé de seus seguidores. Se, no romance de Eugène Sue, o principal objetivo dos jesuítas é chegar à herança dos descendentes de Mario Rennepont e, neste ponto, se movimenta toda a atuação ambiciosa dos padres, na obra alencarina, a atuação de Molina se prende ao roteiro das minas de prata e aos benefícios que ele poderia lhe fornecer. José de Alencar trabalha com algumas indagações e problemas levantados pelo romance folhetim francês, conforme abrange críticas ao modo pelo qual Molina enxerga as doutrinas religiosas, recuperando, neste 
sentido, possíveis reflexões de Eugène Sue sobre as estratégias de manipulação utilizadas pelos inacianos. O loiolano Rodin, de O Judeu Errante, organiza uma Instituição que opera em diferentes países e continentes contra uma família protestante, ao passo que Molina conspira contra seu governo, ao considerarmos que Filipe II também tenta obter o pergaminho das minas.

As obras trazem um teor crítico e moralista com relação à conduta dos inacianos que se mostram argilosos em suas empreitadas. Ou seja, Alencar em nível nacional, dialogando com seu contexto de produção, e Eugène Sue ${ }^{7}$, no contexto pós revolução de 30, amplificam o poder dos jesuítas, ao representarem uma ordem que detém influência em vários países.

No romance de Sue, a Companhia opõe-se aos protestantes e aos reformistas, no de Alencar, com menor ênfase, os jesuítas opõem-se à lei que permite os judeus transitarem na colônia, bem como perseguem os protestantes, de maneira que as narrativas citam ou aludem às perseguições religiosas da época referida em suas obras. Dentro deste contexto mais amplo, podemos levantar alguns pontos tematizados em comum, como o papel dos jesuítas na sociedade, o modo como eles articulam suas doutrinas com seus interesses, e a disputa pelo poder político. O Judeu Errante redimensiona os conflitos entre religião e filosofia, trabalhando os desdobramentos dos confrontos religiosos entre católicos e protestantes, conforme nos atentamos na recepção dessa obra. Proveniente desse quadro, a narrativa literária explora as perseguições da igreja católica contra os reformadores, bem como o quadro de realizações políticas da Corporação que administraria um programa corrupto, antimoralista, completamente ambicioso, em contraste com o quadro de liberdade e tolerância religiosa, simbolizado pela família Rennepont. Nas trocas culturais entre França-Brasil e, sobretudo, na recepção da imprensa fluminense, as críticas contra a literatura jesuítica partem de tópicas e pontos assemelhados e tocantes, gestando querelas que dialogam com o personagem Rodin, e, em menor proporção, com Molina.

\footnotetext{
${ }^{7} \mathrm{O}$ romance se passa na década de 1832 , mas o contexto de sua produção é o da década de 40. Quanto a isso, O Correio Mercantil publica sob o título "Correspondência de Paris" (Correio Mercantil, 16/09/1857, p. 1), um breve quadro das condições de produção de O Judeu Errante, o que contribui para situar o leitor brasileiro: "Soprava então o vento da guerra aos jesuítas. No colégio de França dois professores célebres, Michelet, o grande historiador, Edgar Quinet, espírito assaz original mas pretensioso, faziam todas as semanas lições contra os jesuítas; os seus cursos eram tumultuosos e faziam um grande ruído em Paris; de todos os lados choviam brochuras antijesuíticas. Eugenio Sue teve ainda a habilidade de aproveitar a ocasião. O Judeu Errante era uma ataque em regra contra a ordem.”
} 
As relações de poder exercidas por Rodin, de O Judeu Errante, e por Molina, de As Minas de Prata, articulam-se com as figuras de conspiradores e maquiavélicos de ambos os padres. Tanto um personagem quanto o outro prejudicam pessoas que poderiam ameaçar seus objetivos, caso dos sete descendentes da família Rennepont, em O Judeu Errante, e dos personagens envolvidos com o roteiro, em As Minas de Prata. Usando as ferramentas que poderiam lhe proporcionar vantagens, como $o$ confessionário, os alfarrábios e as cartas, além da própria religião como forma de atrair grandes aliados, ambos deslizam sem serem percebidos. Eles sintetizam a dimensão crítica que emoldura as cenas chocantes em cada obra. Vale pontuar que os contextos de produção são distintos, bem como a própria estruturação das obras. O folhetim de Eugène Sue ganha outras interpretações, como o ataque à igreja católica, ao passo que o romance de Alencar possui um menor alcance, aliado ao fato de Molina passar por um processo de redenção. Rodin estaria bem longe de qualquer atitude de redenção. A reestruturação dos atos maquiavélicos em As Minas de Prata estaria bem distante da perversidade de Rodin. Não obstante, as duas narrativas de teor antijesuítico, para além de lançarem a cartilha secreta dos jesuítas, contribuem na reescrita do mito negativo dos inacianos.

\section{Rodin e Molina: a conspiração da Companhia}

Na primeira parte da obra de $O$ Judeu Errante, o narrador descreve a cartilha secreta dos inacianos, o que abre possibilidades de interação com a crítica da imprensa, posto que o domínio que os inacianos ambicionavam na área da educação, juntamente com a ambição de governar países, bem como suas perseguições religiosas, são elementos consensuais da literatura antijesuítica em nível nacional e internacional. Aliás, as notícias sobre a expulsão dos inacianos em distintos países vêm à baila nesse momento.

Rodin se destaca por sua perversidade e maquinação, ao desestruturar seus inimigos com a tática de atingi-los pelas suas grandes paixões. Sobrepondo-se por seu caráter duvidoso, o inaciano conspira contra os protestantes. O deslizamento da Companhia por diferentes espaços sem ser desmascarada, permite com que ela amplifique seus poderes e ostente uma atuação oculta, como o próprio Rodin afirma. Este dado explorado em $O$ Judeu Errante, por seu caráter intrínseco à movimentação da Ordem Religioso, é reorganizado em As Minas de Prata, não só pela própria 
configuração da representação da Companhia, mas também por ser escancarado pela própria voz de Molina.

No folhetim francês, os inacianos precisam derrubar a conspiração dos protestantes para poderem ganhar a herança, de modo que o arranjo da narrativa traz encontros e desencontros que descortinam o embate entre esses dois vieses conspiradores. Esse elemento conspiratório também é explorado em As Minas de Prata na medida em que Molina se contrapõe não só ao protagonista Estácio, mas, principalmente, ao governo. A conduta do loiolano se aproxima da de Rodin, conforme mobiliza alianças ${ }^{8}$ e, sobretudo, sua função de padre, abusando da fé que as pessoas lhe confia. Já Rodin, com poderes mais amplos, expande sua vingança por outras partes, e conta com diversos tipos de pessoas, o que estende ainda mais o império dos jesuítas. Dadas as diferenças de alcance entre uma obra e outra, podemos constatar que As Minas de Prata promove um complô local, ao passo que $O$ Judeu Errante intensifica tal complô, apontando a ameaça que os jesuítas representam ao mundo. Assim, esse aspecto conspiratório se apresenta com menor teor em As Minas de Prata, dado que Molina maneja sozinho todas as tramas que lhe permitem alcançar o disputado roteiro. Seu principal comparsa seria seu superior, Cláudio Aquaviva.

Em O Judeu Errante, o loiolano consegue atingir a todos pelas emoções. No final, Rodin consegue matar parte dos descendentes.

Tomando este ponto, o alcance das paixões como uma ferramenta que desestabiliza o inimigo, observamos que As Minas de Prata também a explora, pois Molina ataca os personagens Estácio, dono do roteiro, e sua ex mulher Dulce, ao provocá-los por meio do caráter impulsivo e apaixonado que ambos personagens apresentam.

Em outro momento, o padre utiliza o sermão para atingir o governador, dada sua concorrência com o poder governamental. O título do capítulo "Como naquele tempo se

\footnotetext{
${ }^{8}$ A ideia de uma sociedade secreta desenvolvida por Eugène Sue é pensada na narrativa de Alencar, que representa na imagem da reunião dos jesuítas e nas possíveis alianças feitas por Molina as manobras dos inacianos para conseguir alcançar suas finalidades. Essa ideia está presente no momento de escrita da obra. A leitura de que os jesuítas se movimentam através de alianças é explorada em obras sobre a Companhia, e divulgada pela imprensa. Como exemplo, citamos o livro História dos Jesuítas, pelo abade Guettie, divulgada no Correio da Tarde. Segundo sua recepção, o texto conta com documentos inéditos e com questionamentos sobre as intrigas e a políticas astuciosas dos homens de preto. Assim, ele compara a Companhia às sociedades secretas que espalham seus afiliados por todas as classes. (Correio da tarde, $7 / 10 / 1858)$.
} 
fazia oposição ao governador" é bastante significativo, conforme escancara os instrumentos manuseados pelos loiolanos para amplificar seus domínios. Ao utilizar o termo "naquele tempo" a obra abre um diálogo com o presente, deixando em aberto os meios empregados pelos jesuítas na contemporaneidade de Alencar. Dado o contexto colonial, no qual o Colégio do Jesuíta monopolizava as missas, seria mais fácil conseguir alcançar o governador, que, não por acaso, está presente no momento do sermão pregado por Molina.

O sermão de Molina consegue filtrar os principais dogmas da Ordem atacados pelo contexto antijesuítico, bem como os pontos sintetizados da ação da Instituição: a disputa com o poder temporal e a tendência política da Companhia, crítica que acompanha a Instituição até o século XIX; e a concorrência com os senhores de Engenho, crítica local, dado o momento de colonização do Brasil. O lado político da Ordem é revelado em vários momentos da trama, redimensionando significações sobre as propagandas antijesuíticas rearticuladas na obra de Sue.

Rodin e Molina sintetizam em suas maquinações os manejos da Instituição Inaciana, participando dos grandes conflitos das obras. A análise das duas obras possibilita observar que, além do reaproveitamento da temática antijesuítica, elas se aproximam estruturalmente, ao apresentarem ingredientes folhetinescos e ao formalizarem suas críticas à Ordem com aspectos semelhantes.

\section{Conclusão}

O romance histórico de José de Alencar absorve os paradigmas construídos sobre as propagandas antijesuíticas, dadas a ler na porosidade das páginas da imprensa. $O$ folhetim de Eugène Sue e as polêmicas que acalentam os periódicos fornecem, em parte, o quadro de querelas e a produção de sentidos sobre os jesuítas. Nosso recorte tentou delimitar as leituras sobre a Companhia, conforme as especificidades e as características do público leitor. Nesse sentido, a obra alencariana responde ao seu tempo, ficcionalizando os debates da imprensa, alicerçando um movimento de contestação à Companhia e descrevendo os aspectos decadentes dessa Instituição, que chega ao ponto máximo com a expulsão dos jesuítas. Podemos entender que a atualização que a Companhia obteve no seio da Igreja Católica não representa a Ordem que deve permanecer no Brasil. Não é por acaso que Rodin morre na trama de Sue, e 
que Molina se retira ao sertão, sem alcançarem seus objetivos, o que nos permite pensar que ambas as obras sugerem reformas na Companhia, ou mesmo, sua destruição.

\section{Referências:}

ALENCAR, José de. As Minas de Prata. In: Obra completa. Rio de Janeiro: Aguilar, 1958. v. 2.

CHARTIER, Roger. A história cultural: entre práticas e representações. Lisboa: Difel, 1990.

191.

. O mundo como representação. Estudos Avançados, v. 5, n. 11, 1991, p. 173-

Domingos, Simone Tiago. Política e memória: a polêmica sobre os jesuítas na Revista do IHGB e a política imperial, (1839-1886). Dissertação (mestrado na área de História), Campinas: Universidade Estadual de Campinas, 2009.

FRANCO, José Eduardo. O mito dos jesuítas: em Portugal, no Brasil, e no Oriente. Lisboa: Gradiva, 2007. v. II.

LEAL, Mendes. Calabar. LEAL, Mendes. Calabar. Rio de Janeiro: Correio Mercantil, 1863, p.34. v. 3.

LEROY, Michel. O Mito Jesuíta. De Béranguer a Michelet. Trad. José Eduardo Franco. Lisboa: Roma Editora, 1999.

VITORINO, Arthur José Renda. Leitores e leituras de romances franceses em nossas plagas imperiais. Cad. AEL, v.9, n.16/17, 2002.

\section{Fontes Primárias Citadas}

Correio Mercantil

Diário do Rio de Janeiro

Guanabara

A Voz da Religião 